\title{
Italian Young People Through the Lens of Youth Policies'
}

\author{
Davide Mazzoni, Elvira Cicognani, Chiara Cifatte, \\ Cinzia Albanesi, Bruna Zani, Lorenzo Floresta
}

\begin{abstract}
Previous attempts to classify youth policies emphasised the importance of the underlying "concept of youth", which sustains and legitimises specific policy measures. The aim of this study is to identify, through a bottom-up approach, the main orientations which characterise recent youth policies in Italy. Twelve documents (published from 2012 to 2016) at the national, regional and local levels are analysed through content analysis. Four main policy orientations emerge, each characterised by a different representation of young people and solutions/aims. Representing young people as talents often implies an orientation toward skill development; seeing youth as a resource is often associated with the promotion of their possible contribution to the society. Negative representations of youth (as vulnerable and as problems) characterise protective solutions. Each approach is characterised as well by specific risks, strengths and supporting institutions. A useful framework for the analysis of youth policies at the national and international levels is discussed.
\end{abstract}

KEY WORDS $\quad$ young people; youth policies; framing; representations; Italy; policy analysis

\section{Introduction}

Young individuals represent a sector of population that requires specific attention from European institutions. Since the economic crisis in 2008, European youth unemployment rates have been persistently high at around $20 \%$ on average (Caliendo and Schmidi 2016). In Italy, even before the effects of the economic crisis came to a head, the situation for young people was already unfavourable: their activity rate was $30.9 \%$ (compared to an average of $44 \%$ recorded in the EU27), and their employment rate amounted to $24.4 \%$, compared to an average rate of $37.5 \%$ in the EU27 (Dota 2010). Italian young adults tend to leave their parental home later than in other EU countries in order to avoid falling into a persistent poverty state (Ayllón 2015), with a negative impact on other social sectors. In this situation, institutions have the opportunity and the responsibility to influence the status quo,

Sociální studia / Social Studies 2/2018. Pp. 75-96. ISSN 1214-813X.

1 The research reported in this paper was funded by the European Union, Horizon 2020 Programme, Constructing AcTiveCitizensHip with European Youth: Policies, Practices, Challenges and Solutions (www.catcheyou.eu), grant agreement number 649538. The views and opinions expressed in this publication are the sole responsibility of the author(s) and do not necessarily reflect the views of the European Commission. 
moderating the impact of the economic crisis through specific policies which can guarantee the individual's access to education, training, labour market, and welfare.

A youth policy could be defined as "the overarching framework of governmental (and sometimes non-governmental) activity directed towards young people: at, for and with them" (Williamson 2011: 135). Youth policy is often considered a marginal field of social policy, and in many countries the idea of youth as an object of social policy is not really acknowledged (Wallace and Bendit 2009). Moreover, the status of youth policies is in continuous evolution and different institutions focus on different priorities. For these reasons, youth policies are highly diverse not only between countries, but also within countries, being often decentralised towards the regional/local level and the voluntary sector.

To make sense of such complexity, some attempts have been made to classify national youth policies according to a variety of dimensions, resulting in interesting analyses that were published until 2011 (Wallace and Bendit 2009; as regards the Italian context, Villano and Bertocchi 2014). In this article, we examine a selected number of Italian policy documents which were published in the period 2012-2016, in order to describe how the specific representations of and discourses about youth (including both adolescents and young adults) sustained and legitimised the policy measures.

\section{Youth policies in Italy}

In his reconstruction of the history of youth policies in Italy, Mesa (2010) identified several stages. Starting from the local experimentation of the early youth projects initiated in the second half of the 1970s, the process culminated, in 2006, in the opening of a policy sector at the national level by establishing a special Ministry (named "Youth Policies and Sport Activities"). This Ministry was identified as the Italian representative in European arenas on youth policies (POAT 2014). In 2008, the centre-left government was replaced by a centre-right government, but the proxy for youth policies was maintained in a separate and ad hoc Ministry (the Ministry for Youth). Then, from 2011 on (except for a few months in 2013 with the "Ministry for Equal Opportunities, Sport and Youth Policies"), youth policies were delegated to the Presidency of the Council of Ministers - Department of Youth and National Civil Service, currently in charge of the sub-secretary of the Minister of Labour and Social Policy.

In this system, due to lack of coherent policy at the national level in the 1980s and 1990s, the regions became more important for policymaking, bringing the locus of governance closer to young people and localities (Bazzanella 2010; Villano and Bertocchi 2014). More recently, two national organs became relevant for Italian youth policies. The first one is the ministerial ex-department for youth, which in 2012 was replaced by the Italian Department of Youth and National Civil Service. Second, the National Youth Agency (Agenzia Nazionale per $i$ Giovani) is an autonomous organisation, established in 2007 under the auspices of the Italian government and the European Commission. All these actors contribute to define a heterogeneous picture that is characterised by a general discontinuity in resource allocation (Government of Italy n.d.), and suffering also from frequent budget cuts (Guidi 2014; Andersson et al. 2017). 


\section{Representations of youth in policies}

The rejection of rationalistic visions of policy-making, which would start from the assumption that policy ideas always emerge as responses to objective and well-known problems, suggests that experts and interest groups facing similar problems can promote different solutions (Béland 2005). In this sense, critically analysing the ways in which policy language constructs and represents policy problems is important, as these discursive constructions have implications for how institutions are invoked to think about (and justify) possible policy responses (Bacchi 2009). Indeed, the representation of youth that is (more or less explicitly) driven by policies has a key role in, and is part of, the process of "problem structuring": this is probably the most crucial task in policy development, since if a problem is not structured appropriately (i.e. if it does not adequately represent the social or political issue), policy will fail in reaching its goals (Dunn 1981; see also Bradbury 1989).

In more general terms, this idea is consistent with considering social representations as a useful framework for making sense of what institutions consider as socially significant actors and phenomena (Howarth 2006). For this reason, social representations have an impact on political discourses, laws, and regulation (Andreouli and Howarth 2012; Andreouli, Howarth and Shose 2014). Wallace et al. (2009: 444) suggest that the underlying "concept of youth", defined as the extent to which young people are seen as a problem or as a resource, represents an important factor that distinguishes youth policies in different part of Europe (see also Chisholm, Kovacheva and Merico 2011). This is consistent with the work by Walther, Moerch Hejl and Benchmann Jensen (2002), who suggest that the ambition of such problem-resource-thinking is to provide a useful categorisation-instrument concerning different youth policies (Walther et al. 2002). In this regard, previous analyses in Italy have shown that the political agenda tends to see them more as a "problem" than as a "resource" (Villano and Bertocchi 2014).

However, such a dualistic classification has received some criticism, since the distinction between problem and resource is not defined by absolute criteria and depends on how young people are evaluated by institutions (Walther et al. 2002). In this sense, the classification of youth as "problem vs. resource" does not clearly explain much more than a general evaluation of youth in positive or negative terms by society. The first aim of our work was thus to obtain, thorough a bottom-up approach in the study of youth policies, a more detailed description and classification of the underlying representations of youth in the Italian context.

Second, the importance of studying the representations of youth mostly resides in the claim that, even in the absence of clear evidence, there is a relationship between the underlying representation of youth and the specific aims/solutions which are proposed by a policy (Wallace et al. 2009; see also IARD 2001; Andersson et al. 2017). Thus, a further aim of our study was to investigate such relationships, identifying and describing recurrent connections. Both aims were pursued analysing a group of Italian policy documents.

In summary, the purpose of this manuscript is thus to describe and to classify the underlying representations of youth in a sample of Italian youth policy documents and to investigate the relationships between the underlying representations of youth and the specific aims/solutions which are proposed. 


\section{Method}

Our research was conducted in the framework of the H2020 project CATCH-EyoU (Constructing AcTive CitizensHip with European Youth). Following the project protocol, researchers used different strategies to identify possible candidate documents for analysis. Web searches through search engines and databases were accompanied by direct requests for suggestions from policy experts at the national and regional levels (policy makers, politicians, representatives of youth organisations).

More specifically, the web searches were based on the consultation of online archives containing many regional youth policies, like Politichegiovanili.it ${ }^{2}$. Ad hoc Google searches were performed combining the search term "youth policies" (in Italian) with the name of each Italian region. The request for suggestions from policy experts at the national and regional levels was performed in a previous interview-based study, part of the CATCH-EyoU project (Cicognani and Amnå 2016). Such experts were asked to identify documents that could well represent the point of view of their institution.

Because previous analyses of Italian youth policies were published before 2012 (e.g. Villano and Bertocchi 2014), a preliminary list of documents published between 2012 and 2016 was created. The list was drafted by the first three authors and it was revised by the others. All the documents were freely available online.

Due to the lack of a broader national framework on youth policies in Italy (as a specific policy domain) and the regional specificities in the way youth policies are addressed, we included in the analyses different types of documents. Indeed, for the purposes of this study, we took advantage of documents produced at the national level within other policy areas which target young people (e.g. employment). Moreover, we also considered policy documents which were produced in some Italian regions during the time interval of interest, and these we considered particularly interesting examples of the different approaches and heterogeneity which characterise the Italian context. All the documents were available online as full texts.

Table 1 presents the final list of documents that were selected and analysed. It includes documents that can be located at different geographical and institutional levels. The documents were produced by different institutions (public and private), demonstrating the overall trend towards cross-sectoral cooperation in the formulation of youth policies. More specifically, documents 1-3 refer to the national level, while documents 4-12 refer to the regional-local level. Documents 2 and 3 were produced by youth organisations, while documents 1 and 4-12 were published by governmental agencies (at the national, regional, and local levels). Overall, the selected documents reflect the importance of inter-professional and cross-sectoral cooperation among the social, health, and education services as a strategy for community development.

As regards the legal and practical value of the documents, our list mostly focuses on strategic plans of action, due to the possibility of linking, in the same document, the specific social framework (depending on the problem structuring) with the specific aims/ solutions. The formal value of the legal documents, as well as the practical consequences of the policy implementation (see (McLaughlin 1987), were not the focus of our work.

2 http://www.politichegiovanili.it/ 
In this sense, even with a great deal of variability across different dimensions, including the public/private sphere and the level of abstraction, all the documents contained a reflection on condition of Italian youth, accompanied by actions.

Table 1: Documents list

\begin{tabular}{|c|c|c|c|c|c|}
\hline N. & Document name & Level & $\begin{array}{l}\text { Main policy } \\
\text { area }\end{array}$ & Age group & $\begin{array}{c}\text { Publication } \\
\text { year }\end{array}$ \\
\hline 1. & $\begin{array}{l}\text { Italian Youth Guarantee } \\
\text { Implementation Plan }\end{array}$ & National & $\begin{array}{l}\text { Employment - } \\
\text { school to job } \\
\text { transition }\end{array}$ & $\begin{array}{l}\text { Young individuals } \\
\text { (around } \\
15-29 \text { y.o.) }\end{array}$ & 2013 \\
\hline 2. & $\begin{array}{l}\text { Italian Youth Forum - Plan of actions } \\
\text { 2012-2015 }\end{array}$ & National & Multiple & Young individuals & 2012 \\
\hline 3. & $\begin{array}{l}\text { Direct contact with second } \\
\text { generations - Our Manifesto in } 10 \\
\text { points }\end{array}$ & National & Multiple & $\begin{array}{l}\text { Young individuals } \\
\text { (from children } \\
\text { to young adults) }\end{array}$ & 2014 \\
\hline 4. & $\begin{array}{l}\text { Promotion of wellbeing and risk } \\
\text { prevention in adolescence: "Project } \\
\text { adolescence", Regional guidelines }\end{array}$ & $\begin{array}{l}\text { Regional } \\
\text { (Emilia } \\
\text { Romagna) }\end{array}$ & Health & Teenagers & 2013 \\
\hline 5. & $\begin{array}{l}\text { Approval of the agreement } \\
\text { on youth policies between Region } \\
\text { Emilia Romagna and the Presidency } \\
\text { of the Council of Ministers - } \\
\text { Department of Youth - year 2013, } \\
\text { "Evolved and aware youth" }\end{array}$ & $\begin{array}{l}\text { Regional } \\
\text { (Emilia } \\
\text { Romagna) }\end{array}$ & $\begin{array}{l}\text { Youth } \\
\text { engagement }\end{array}$ & $\begin{array}{l}\text { Young individuals } \\
\text { (around } \\
14-30 \text { y.o.) }\end{array}$ & 2013 \\
\hline 6. & $\begin{array}{l}\text { Strategic guidelines for } \\
\text { the implementation of the Youth } \\
\text { Guarantee Piemonte - years } \\
2014-2015\end{array}$ & $\begin{array}{l}\text { Regional } \\
\text { (Piedmont) }\end{array}$ & $\begin{array}{l}\text { Employment - } \\
\text { school to job } \\
\text { transition }\end{array}$ & $\begin{array}{l}\text { Young individuals } \\
\text { (around } \\
15-24 \text { y.o.) }\end{array}$ & 2014 \\
\hline 7. & $\begin{array}{l}\text { Youth Plan } 2013 \text { - Approval } \\
\text { of calls "Creation, improvement, } \\
\text { and continuity lab and business } \\
\text { incubators and youth spaces" }\end{array}$ & $\begin{array}{l}\text { Local } \\
\text { (Provence } \\
\text { of Novara - } \\
\text { Piedmont) }\end{array}$ & $\begin{array}{l}\text { Employment - } \\
\text { innovation }\end{array}$ & $\begin{array}{l}\text { Young individuals } \\
\text { (around } \\
15-30 \text { y.o.) }\end{array}$ & 2014 \\
\hline 8. & $\begin{array}{l}\text { [All youth are a resource. Aims } \\
\text { and strategies of "Bollenti Spiriti", } \\
\text { programme of the Region Puglia } \\
\text { for youth policies 2014-2015] }\end{array}$ & $\begin{array}{l}\text { Regional } \\
\text { (Puglia) }\end{array}$ & $\begin{array}{l}\text { Employment - } \\
\text { innovation }\end{array}$ & $\begin{array}{l}\text { Young individuals } \\
\text { (around } \\
15-24 \text { y.o.) }\end{array}$ & 2013 \\
\hline 9. & $\begin{array}{l}\text { Regional law, March } 22,2012 \text {, n. } 5 \\
\text { Law for youths' autonomy and for } \\
\text { the Guarantee Fund for their } \\
\text { opportunities }\end{array}$ & $\begin{array}{l}\text { Regional } \\
\text { (Friuli } \\
\text { Venezia } \\
\text { Giulia) }\end{array}$ & Multiple & $\begin{array}{l}\text { Young individuals } \\
\text { (around 14-35) }\end{array}$ & 2012 \\
\hline 10. & $\begin{array}{l}\text { Regional law, February } 1,2016, \mathrm{n} .1 \\
\text { Norms about youth policies - further } \\
\text { specifications }\end{array}$ & $\begin{array}{l}\text { Regional } \\
\text { (Umbria) }\end{array}$ & Multiple & $\begin{array}{l}\text { Young individuals } \\
\text { (around } \\
14-35 \text { y.o.) }\end{array}$ & 2016 \\
\hline 11. & $\begin{array}{l}\text { Regional law, October 14, } 2011 \text { - } \\
\text { and Annex A } \\
\text { Approval of the "Three-year } \\
\text { program 2010-2012" of interventions } \\
\text { for youths }\end{array}$ & $\begin{array}{l}\text { Regional } \\
\text { (Lazio) }\end{array}$ & Multiple & $\begin{array}{l}\text { Young individuals } \\
\text { (around } \\
14-35 \text { y.o.) }\end{array}$ & 2011 \\
\hline 12. & $\begin{array}{l}\text { Regional law, August 8, 2016, n. } 26 \text {. } \\
\text { "Building the future: New politics } \\
\text { for youths" }\end{array}$ & $\begin{array}{l}\text { Regional } \\
\text { (Campania) }\end{array}$ & Multiple & $\begin{array}{l}\text { Young individuals } \\
\text { (around } \\
16-34 \text { y.o.) }\end{array}$ & 2016 \\
\hline
\end{tabular}


The process of analysis started with the reading of each document several times to familiarise with its content. Statements describing youth (young individuals, youth as a category, or related sub-groups) were thus identified. In a second step, following a thematic content analysis (Braun and Clarke 2006), each statement was then grouped according to its more or less explicit representation of youth. Statements were analysed by two researchers. Results were revised by a third researcher.

\section{Results}

Most of the documents under analysis fall within multiple policy areas, including employment, school-to-job transition, civic and political engagement, and, to a lesser extent, health promotion. Most of them consider a broad range of ages (from 14-16 to 30-35 years old) as final beneficiaries of the actions. In the analysis, we identified four main representations of youth in Italy, which we labelled as follows: vulnerable youth, young talents, youth as problem, and youth as resource. These four representations can be placed on a plane that is oriented by two axes, which correspond, respectively, to negative-positive and individual-societal perspectives (see Figure 1).

Figure 1: The four main representations of youth in Italian policy documents (2012-16)

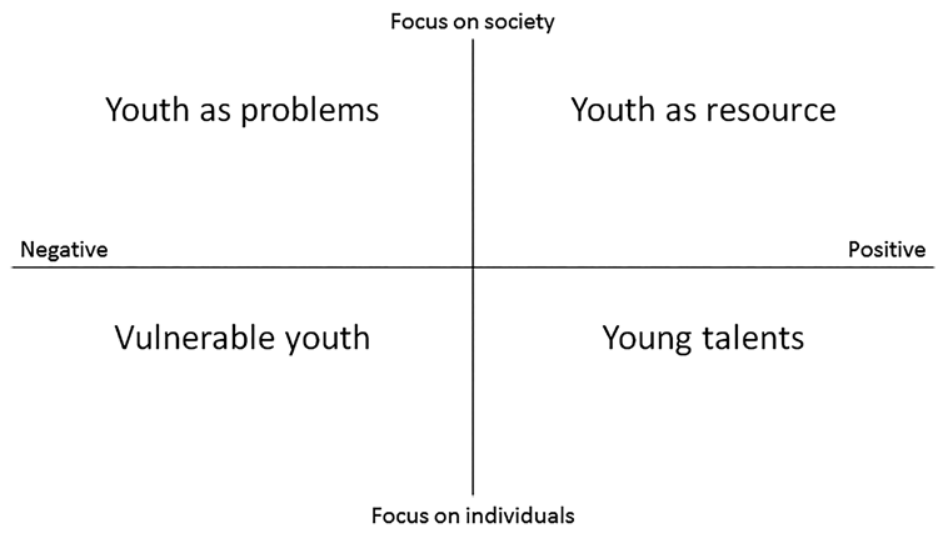

Considering the complexity and the articulation of the documents under study, it is not possible to determine a single representation of youth characterising each document. In a single document, we often registered more coexisting representations of youth and multiple aims. For example, in document no. 8, the representation of youth as resource coexists with some references also to youth as victims: "youth are the main victims of the crisis and the only way to get out of it" (pp. 3-4). Similarly, in document no. 4, the representation of vulnerable youth coexists with some references to youth as resource. To have a more detailed picture, Table A1 (in Appendix) summarises the different representations of youth that are present in each document, with examples of quotes. In the same table, there is also a synthesis of the main 
aims which characterise each document. From our analysis of this group of documents, we present here some conclusions about the relationship between youth representations and policy aims.

\section{Vulnerable youth}

This representation of youth characterises documents that describe youth who, due to their condition, face specific challenges that result in possible diseases, vulnerabilities, or suffering. For example, the vulnerability of youth is quite well exemplified by document no. 4, from the Regional Service of Family, Children and Adolescents of the Emilia Romagna region. The document refers to adolescents' main issues in terms of "risk behaviour" and, specifically, school dropout, bullying and violent behaviour, and addiction. These are all related to the vulnerabilities that teenagers face in their psychological development and to the lack of healthy relationships and/or supportive environments in their lives. Similarly, document no. 12 (from the Campania region) refers to "risk factors and juvenile deviance" (p. 1). Sometimes, the vulnerability is attributed to specific sub-groups, due for example to their health and gender. In this regard document no. 3, which was produced at the national level with reference to immigrant youth, particularly emphasises the vulnerabilities connected with an immigrant background. On the other hand, documents no. 1 and no. 6, which regard the implementation of the Youth Guarantee programme at the national and regional levels, describe youth as vulnerable because they have been particularly damaged by the economic crisis. A similar reasoning can be found also in documents no. 11 (Region Lazio) and no. 8 (Region Puglia).

The representation of youth as vulnerable appears useful to justify educational and caring approaches (as in document 4 ), in which youth are framed as users/targets of the services. This is the case for some interventions in the field of health promotion and risk prevention, which are carried out by regional institutions. However, we can also note that minor references to this representation are also present in documents authored by youth organisations. In such cases, the description of youth as vulnerable is useful to justify the specific attention for this sector of society.

\section{Young talents}

This representation characterises documents that refer to young individuals in terms of their knowledge, skills, and competences, without explicitly referring to the relevance of such qualities for the community or society. This describes document no. 8 from the Puglia region which, even if in a few sentences, attributes some positive qualities to youth. In some cases, youth are described as talents with reference to their possible return to the region of origin or the assignment of ad hoc prizes (document no. 9, from Region Friuli Venezia Giulia). Recognising youths' talents can also be the basis for justifying a participative approach (as in document no. 9) or to further support a representation of youth as a resource (like document no. 3), as described in the section below.

The representation of youth as talents is enough to justify investments in such talents, as well as the promotion of skills development and new forms of youth entrepreneurship 
(see document no. 7). For example, paraphrasing document no. 9, we can say that as much as the institutions recognise the qualities of youths (including their autonomy), the more they support their realisation. Recognising youths as talents implies the necessity of a collective effort to assist such talents to grow up. In practical terms, this representation allows institutions to propose measures which consist of the creation of a fertile environment in which the intrinsic talents of young individuals can develop.

\section{Youth as problem}

This representation of youth characterises documents that describe specific aspects of the youth condition that represent a possible threat to their communities. In this regard, we found that a minority of policies in our study considered youth as problems for the society. Among them, policies about the implementation of the Youth Guarantee programme (no. 1 and no. 6) emphasised the negative social impact that youth unemployment has for the EU and for society in general. However, we must also recognise that, rather than communicating the idea that "youths are themselves the problem", these documents adopt the problematic representation to argue the idea that "youth problems (like unemployment) should be taken seriously" by the whole society. In other cases, youth are described as possible sources of problems in the documents that have to do with bullying and cyberbullying phenomena (document no. 10, from Region Umbria).

The focus on youth problems (e.g. in documents 1 and 6), rather than prescribing a specific role to youth, appears to be useful to justify a policy focus on a specific issue (like unemployment). Indeed, according to this logic, addressing some specific "youth issues" represents an instrument to protect society, defending it from a possible threat. In this sense, the adoption of this representation of youth by institutions is useful to demonstrate that, in any case, the adopted measures will be useful for the whole society, and not only for a specific sector (i.e. young individuals).

\section{Youth as resource}

This representation characterises documents which focus on the possible contribution that, under certain conditions, youth are able to give to their communities and to society in general. Among the documents that more explicitly exemplify this perspective we have document no. 8 (Region Puglia) and 10 (Region Umbria). Document no. 8 consists of a set of interventions and actions to allow the young citizens of Puglia to take part in all aspects of their community life. The idea behind this programme is to clearly consider youth as a resource and not as a problem. The explicit focus is on youths' power and willingness to participate. This idea is reflected also in the role that is attributed to youth, that is, as "active actors" in a process of regional and community development. Document no. 10, from the beginning, states that the region acknowledges youth as an essential resource for the community. In document no. 5 (from Region Emilia Romagna), young people are described as a resource and an incentive for the development of the local community, capable of making a significant contribution in terms of knowledge, expertise, creativity, and innovation. In document no. 11 (Region 
Lazio), youth are seen as co-producers of goods and services, and in document no. 12 (Region Campania) they are described as wealth for their territories.

It is only the presence of the representation of youth as a resource (e.g. in documents no. 4, no. 5 and no. 7) that justifies the explicit inclusion of some policy aims that concern an increase in youth contribution to society. This is the case, for example, of document no. 9, in which considering youth as an "essential resource" implies the centrality of youth policies as a "necessary condition for innovation, sustainable development, and the human, social, occupational, cultural, economic growth of the region" (p. 1). In other words, considering youth as a resource implies making an effort to provide young generations with the opportunity to actively take part and contribute to the life of their community in all its domains, including the political sphere. Similar to the representations of young individuals as problems, the adoption of this representation by institutions is useful to demonstrate that, in any case, the adopted measures will be useful for the whole society, and not only for a specific sector of it.

\section{Discussion}

In this contribution, we described four main representations of youth that emerged from the Italian policy documents under study: vulnerable youth, young talents, youth as problem, and youth as resource. Previous research (Wallace et al. 2009) has suggested that it is possible to distinguish between policies that consider youth as problems versus a resource. However, this distinction appeared mostly focused on the evaluation that society makes of youth, who can respectively represent a "source of problems" or a "source of solutions". This distinction thus does not cover the broad spectrum of policies in which youth are described both in terms of their intrinsic characteristics and their relationship with society. In the following paragraphs, we discuss each of the representations we identified, in the light of the literature.

\section{Vulnerable youth}

Among youth, it is possible to identify vulnerable groups who, for many reasons, require specific attention from authorities and institutions. This idea of youth is implicit in the Italian Constitution, which in Article 31 states "The Republic [...] protects maternity, childhood and youth [...]." The state thus appears particularly interested in specific minorities that may be considered "vulnerable" because of the conditions and threats that characterise their generation, their health, and their economic or migrant status. The most vulnerable young people are, for example, those from multi-problem families: immigrants, young homeless people, uneducated rural youth, school drop-outs, and some ethnic minority youth (Suriala 2006).

In the documents under study, like nos. 3 and 4, we found some specific referrals to these categories and we suggest also that others could be found in policies which are not usually labelled as "youth policies" (e.g. health, assistance etc.). We must note that one of the documents (no. 4) that adopted this representation specifically focused on adolescents. Indeed, from a policy point of view, each life phase is characterised by different desires 
and needs, and adolescence may represent a particular "vulnerable period" (Wolf et al. 2004: 74).

Moreover, in the documents we analysed (like documents nos. 1, 6 and 8) we also found that young individuals in general are increasingly considered vulnerable and disadvantaged, mostly for economic reasons. As suggested in the work by Guidi (2014), in recent decades youth has progressively become a vulnerable segment of European societies. Indeed, the 2008 crisis, recession, and austerity politics have exacerbated the already existing difficulties of European young people, especially in some countries (Eurofound 2014; OECD 2014). In the aftermath of the 2008 crisis, the transition to adulthood has been and continues to be uncertain and frustrating for many European young people (Cordella and Masi 2012; Heinz 2009) and in this sense, they represent a vulnerable group.

\section{Youth as talents}

Instead of focusing on vulnerabilities and deficits, this representation focuses on the unique positive qualities that characterise youth. For example, one of the documents under analysis (no. 11) refers to "youths' creativity and talents in relation with professions of visual arts, music and multimedia". The EU also attributes to them many qualities and skills. Indeed, "Young people value friendship, respect, tolerance and solidarity and this generation is perhaps the highest-educated, technically-advanced, and most mobile ever" (European Commission 2009: 2). These arguments are used, in Italy and at the European level, to support the development of young people's talent and entrepreneurial skills (Council of the European Union 2012).

However, even if helping young people to develop their talents is a worthy enterprise, some authors also warn about the risks connected with considering talent development (e.g. through highly competitive calls) the main goal. More specifically, they stress the importance of encouraging high-potential young people to develop their talents towards relational altruistic life trajectories as opposed to egoistic individualism (Ambrose 2003). Indeed, from a pedagogical point of view, excessive egoistic individualism can lead young individuals away from optimal self-fulfilment and will incline them to make unethical sociopolitical decisions when they inherit socioeconomic and political power.

\section{Youth as problem}

Historically, in Italy the representation of youth as "problems" was common during the first years of the 1980s and the early 1990s. Indeed, in that period we faced an increase in publications about drug addiction and juvenile delinquency, with a new series of studies on the youth condition and related issues (Mesa 2010). More recently, as suggested by the documents under study (no. 6 in particular), the problem of youth is increasingly related to economic issues. This is consistent with the fact that the representation of youth "as a problem" may prevail in periods of economic crisis and political instability (IARD 2001). At this regard, Chevalier and Palier (2014) recently reported that the social problem of "youth" emerges when there is a misfit between the compulsory school-leaving age, 
entry into the labour market, and access to full social citizenship, since it raises the problem of personal financing during this period (see also MacDonald and Marsh 2001).

We believe that the representation of youth as problems is quite risky, to the extent it contains the risk of confusion (and even identification) of individuals with their problems, while it could be better replaced by the idea of youth with problems (see also Suriala 2006). Indeed, the concept of "problem youth" refers to young people with objective and intrinsic problematic qualities. The responses to such problems imply the construction of alliances with other societal sectors. On the other hand, the concept of "youth problems" emphasises the fact that young people may face many specific problems (like unemployment, labour market insecurity, increased economic dependency, polarisation, weak social security, use of alcohol and drugs, psychic and psycho-physical symptoms, and so on) which are historically and geographically located and do not exclude young individuals for their solution.

\section{Youth as resource}

The fact that youth are possible resources has ancient origins. As noted by Ambrosi and Rosina (2009), the Latin word "iuven" (young) has the same root word of the verb "iuvare" that means "to be useful, to contribute" to the common good. According to this, a number of scholars suggest that the future and the success of our society depend on youth (Bazzanella 2010). However, our results also emphasise that the specific contribution that youth are supposed to make to society can vary across policies, for example in terms of knowledge, expertise, creativity (document 5), and innovation (documents nos. 3, 5 and 8), for the co-production of goods and services in the communities (document no. 11).

These ways of considering youth as a wealth for their localities and promoting their participation in society, are also consistent with the World Programme of Action for Youth (United Nations 1996: 25): "The capacity for progress of our societies is based, among other elements, on their capacity to incorporate the contribution and responsibility of youth in the building and designing of the future. In addition to their intellectual contribution and their ability to mobilise support, they bring unique perspectives that need to be taken into account". From this point of view, considering youth as resource represents, to the extent it does not remain a mere rhetoric exercise, a real opportunity for giving to the younger generations the opportunity to act and to influence our society as (real) citizens.

\section{Concluding discussion}

One of the advantages of our proposed typology is that it defines some dimensions (negative-positive and individuals-society), according to which each policy can be placed on a continuum, taking into account the possibility of coexisting representations. The four representations can be summarised in two-dimensional graphical form, where the two axes respectively correspond to negative-positive and individual-societal perspectives. Each youth policy can be graphed as a single point (e.g. talents or resource), or as more than one. The latter was the case for most of our documents, in which the different representations can coexist by supplementing and accentuating each other. 
Moreover, our study found preliminary and original evidence of a possible relationship between representations and aims of youth-related policies in the Italian context, and this may have important implications. When youth is described in terms of talents, it means that they should be provided with the best opportunities for development. For example, in document 7 , one aim was to guarantee access to spaces in which youth can develop their creativity and their interests. When youth is described as a resource, society can receive a functional gain by letting them have a protagonist role in their communities. For example, in document 12 one aim was to acknowledge youths as protagonists and active citizens, as an important contribution to individual and community wellbeing. On the other hand, when youth are perceived as vulnerable or as problems, other measures are more willing to be taken: such as taking care of them within the framework of health promotion and risk prevention (as in document 4) and protecting society from negative consequences (document 6). Our work could thus be translated into useful inputs and questions for the policymaking process. Which representations of youth are policymakers endorsing? Are the proposed solutions consistent with such representation? We believe that this line of thought can lead to an improvement in the quality of national youth policies, according to the most recent EU directives.

The implications of our approach also have to do with the representations of youth and their participation in society. Indeed, as expressed by Jones and Gaventa (2002: 13) "the way in which people understand themselves as citizens is likely to have a significant impact on their rights and obligations and on whether they participate, in what form and why". In this sense, it is reasonable to believe that the specific role that is attributed to young individuals will influence the way in which they act as citizens (see also Benedicto and Morán 2007).

The fact that we found many references to youth in the positive space of the graph in Figure 1, is consistent with a temporal perspective of analysis, suggesting that in recent decades there has been a gradual shift in Italy from a protective approach by public institutions to the promotion and development of young personalities in transition (D'Elia 2006). This shift is consistent with a similar European tendency in the late 1990s that placed the representation of youths as vulnerable/problems, which is changing in the $21^{\text {st }}$ century (Helve, Leccardi and Kovacheva 2011). However, we warn that focusing on young individuals' knowledge and competences (i.e. talents) without explicitly referring to the relevance of such qualities for the community or society (i.e. resources) could lead some "talented" individuals to gain an advantage from the policy implementation, leaving others behind and creating a stratified system.

Finally, some limitations of this study should be recognised. First, we focused on a small sample of policies that are mostly relevant at the national level, without considering, for example, the EU level. However, we believe that this work extends the conceptual coordinates for the analysis of youth policies, which could be useful for a future comparative analysis at an international level.

Second, from our non-representative sample, it was not possible to systematically compare differences related to the geographical and institutional level (e.g. national vs. regional) and the related level of abstraction (e.g. general strategic documents vs. "actual" policy documents). Related to this point, another limit of this analysis is that by focusing on the explicit content of the policy documents, we did not consider the potential 
consequences of their concrete implementation. However, by focusing on the "problem structuring" of policies, we do not want to reduce the importance of their implementation. As reported by some authors (Mesa 2010; Villano and Bertocchi 2014), in Italy there is a large gap between the rhetoric of institutional principles and the real praxis of youth policies. In this sense, it is possible that the though a document emphasises the idea of youth as talents or a resource, it is not followed by a concrete plan to give value to their qualities. To overcome this limit, future research could triangulate the sources of information. For this reason, the CATCH-EyoU project devotes specific attention to how policies are concretely received and implemented by politicians, public officials and youth organisations. 


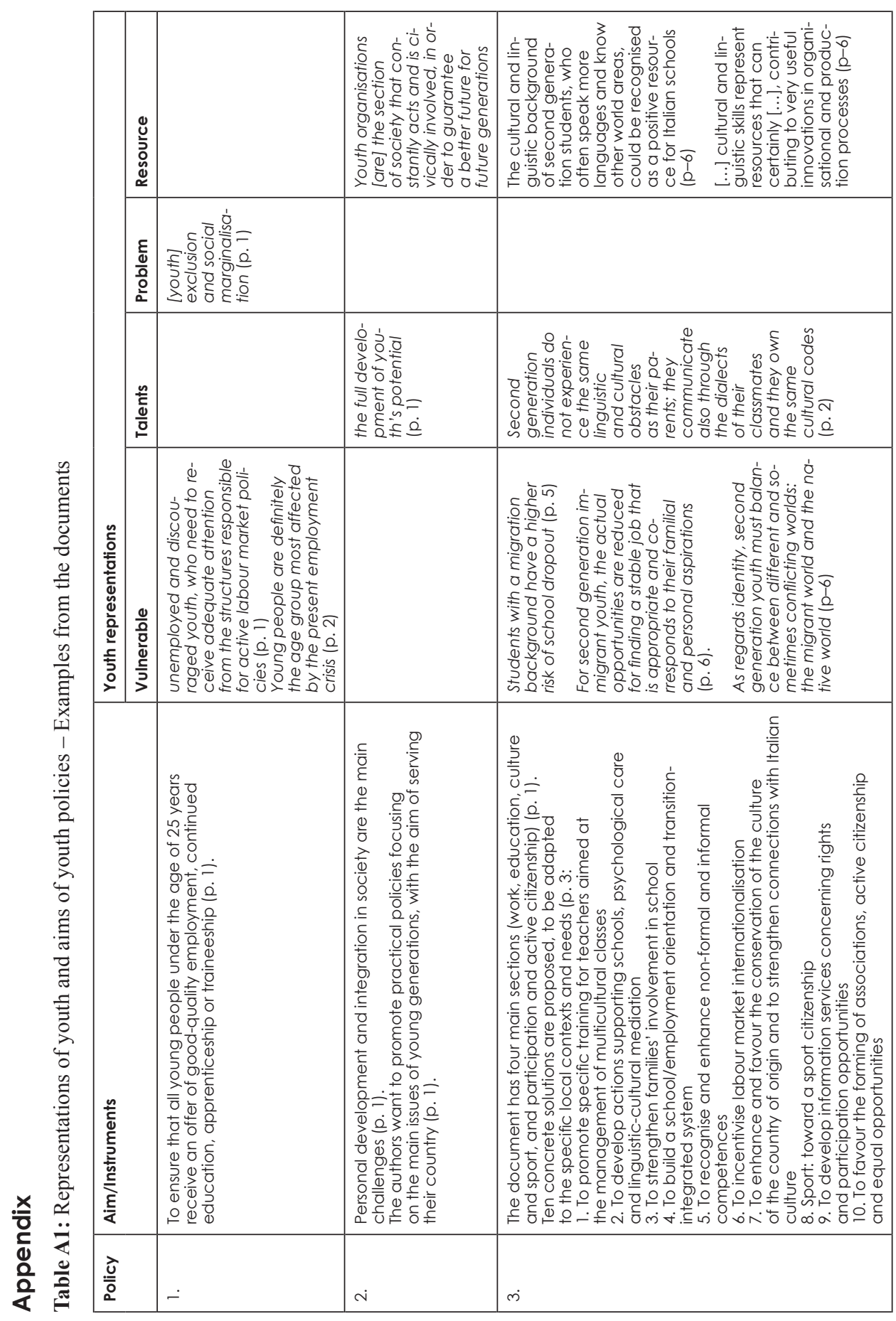


D. Mazzoni, E. Cicognani, Ch. Cifatte, C. Albanesi, B. Zani, L. Floresta: Italian Young People...

\begin{tabular}{|c|c|c|c|}
\hline & 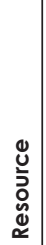 & 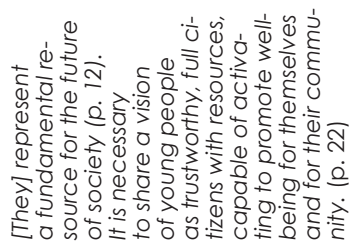 & 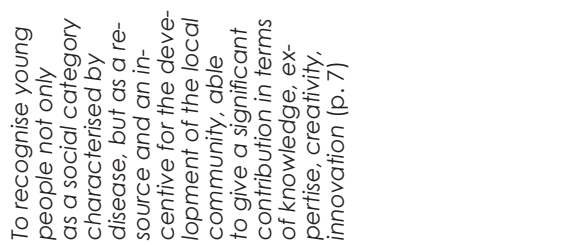 \\
\hline & $\begin{array}{l}\varepsilon \\
\frac{\varepsilon}{0} \\
\frac{0}{0} \\
\end{array}$ & & \\
\hline & $\begin{array}{l}\frac{n}{c} \\
\frac{\omega}{0} \\
\frac{0}{0}\end{array}$ & & 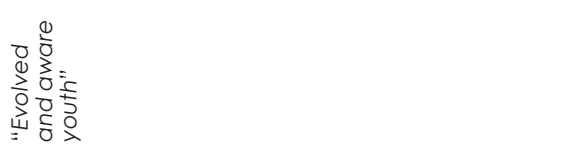 \\
\hline 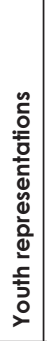 & $\begin{array}{l}\frac{0}{0} \\
\frac{0}{0} \\
\frac{0}{5} \\
>\end{array}$ & 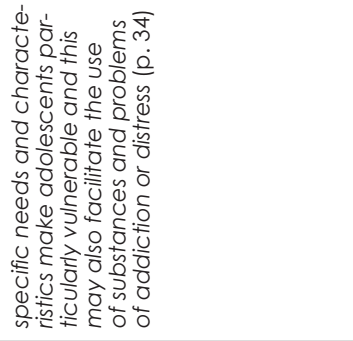 & \\
\hline \multicolumn{2}{|l|}{ 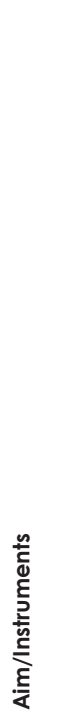 } & 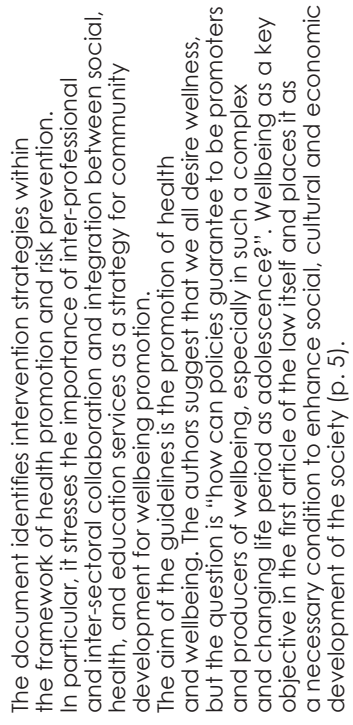 & 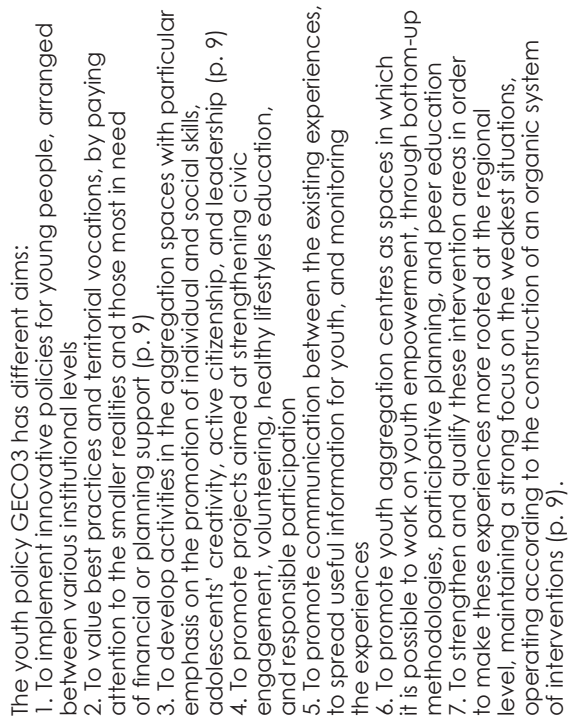 \\
\hline 흥 & & $\dot{\nabla}$ & 'ن \\
\hline
\end{tabular}




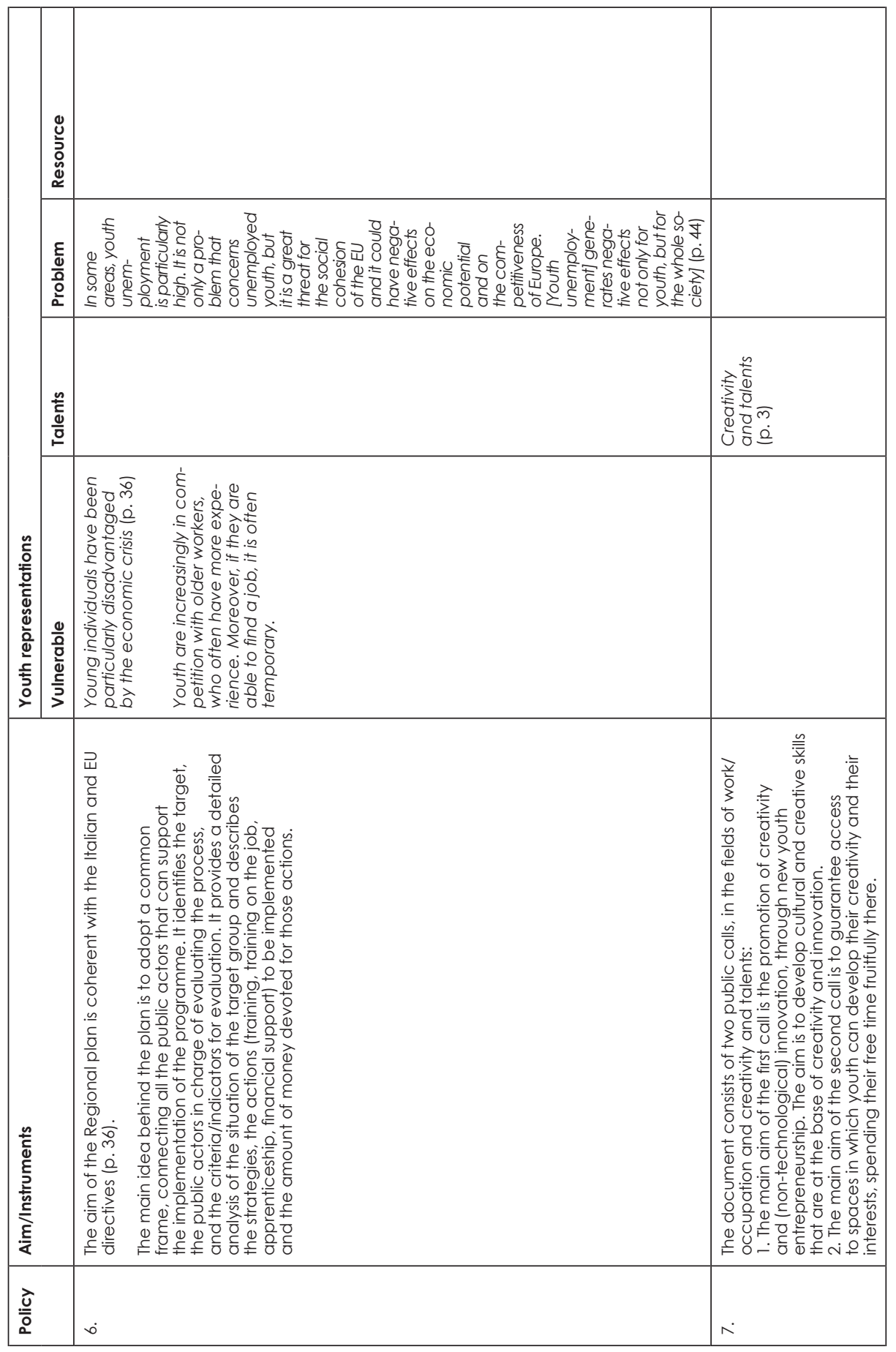


D. Mazzoni, E. Cicognani, Ch. Cifatte, C. Albanesi, B. Zani, L. Floresta: Italian Young People...

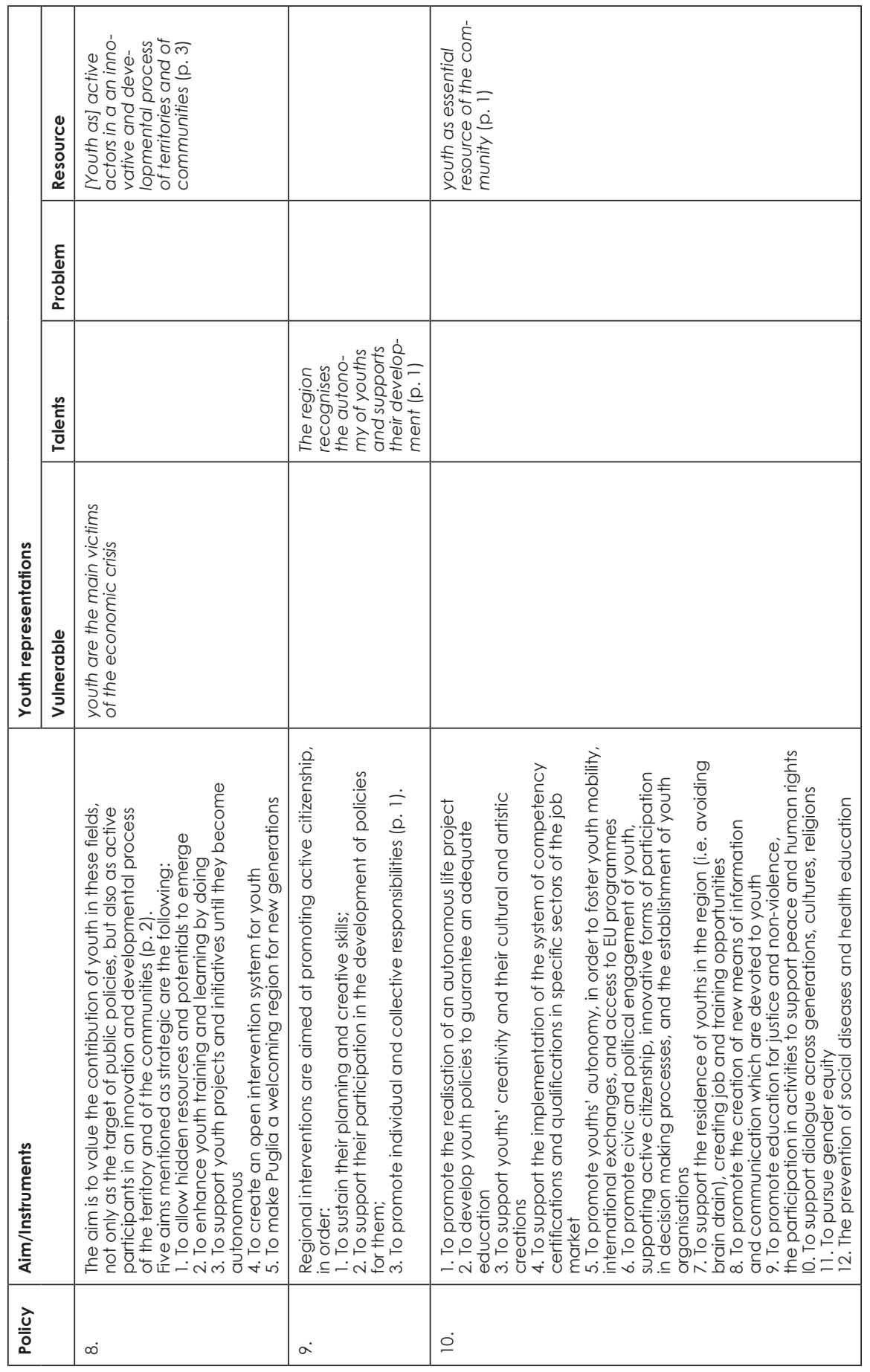




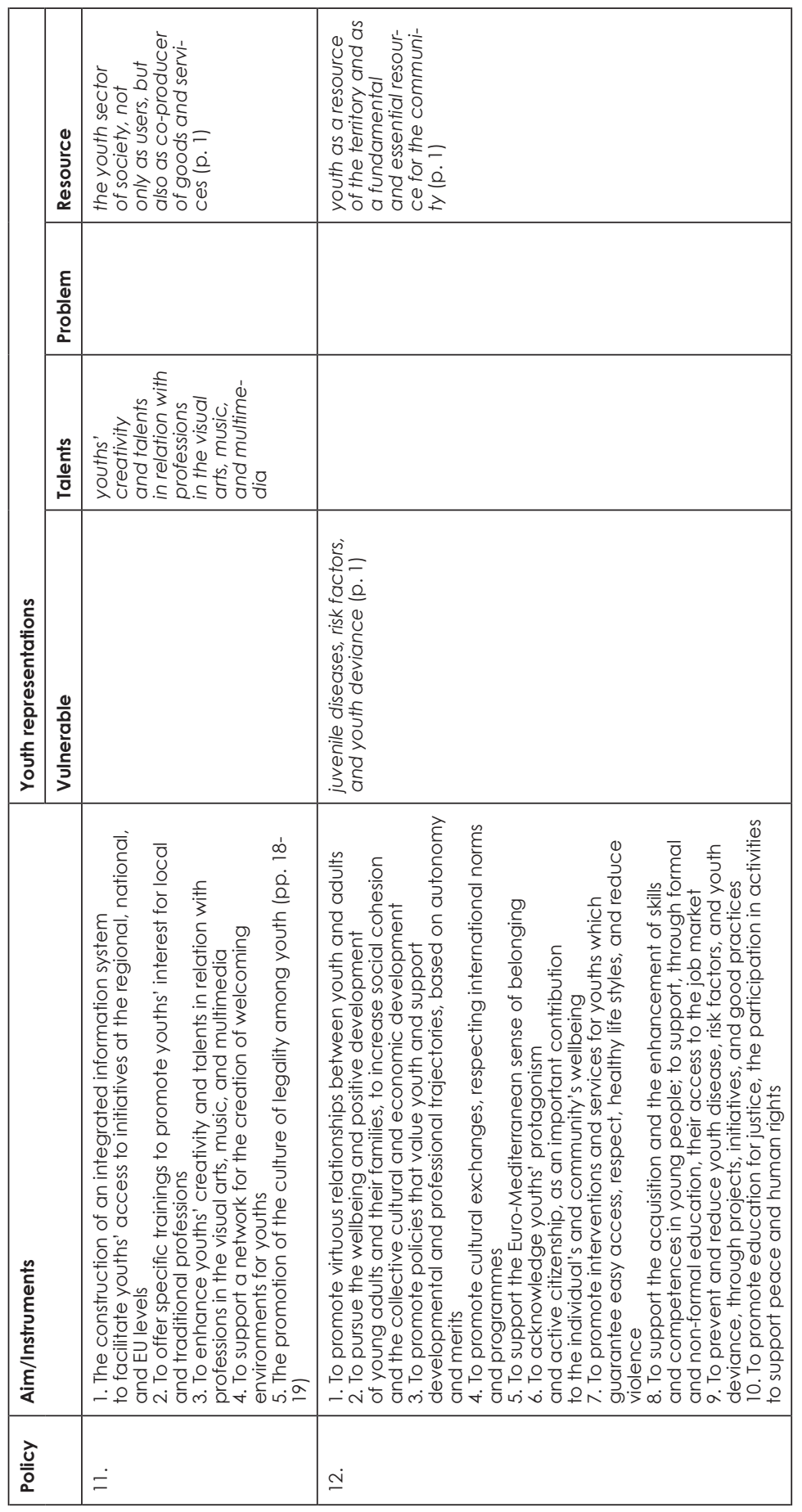




\section{References}

AMBROSE, Don. 2003. "Barriers to Aspiration Development and Self-fulfillment: Interdisciplinary Insights for Talent Discovery." Gifted Child Quarterly 47: 282.

AMBROSI, Elisabetta and Alessandro ROSINA. 2009. Non è un Paese per Giovani: L'Anomalia Italiana: una Generazione Senza Voce. Venice: Marsilio Editori.

ANDERSSON, Björn, Morena CUCONATO, Nicola DE LUIGI, Silvia DEMOZZI, Torbjörn FORKBY, Marta ILARDO, Alessandro MARTELLI, Ilaria PITTI, Dario TUORTO and Federico ZANNONI. 2016. Partispace - Deliverable 2.2 Comparative Report. Zenodo.

ANDREOULI, Eleni and Caroline HOWARTH. 2012. "National Identity, Citizenship and Immigration: Putting Identity in Context." Journal for the Theory of Social Behaviour 43(3): 361-382.

ANDREOULI, Eleni, Caroline HOWARTH and Kessi SHOSE. 2014. "Social Representations and the Politics of Participation." Pp. 19-38 in The Palgrave Handbook of Global Political Psychology, edited by Catarina KINNVALL, Tereza CAPELOS, Henk DEKKER and Paul NESBITT-LARKING. Basingstoke: Palgrave Macmillan.

AYLLÓN, Sara. 2015. "Youth Poverty, Employment, and Leaving the Parental Home in Europe." Review of Income and Wealth 61(4): 651-676.

BACCHI, Carol Lee. 2009. Analysing Policy: What's the Problem Represented to Be? Sydney: Pearson Education.

BAZZANELLA, Arianna. 2010. Investire Nelle Nuove Generazioni: Modelli di Politiche Giovanili in Italia e in Europa. Trento: Editore Provincia Autonoma di Trento - IPRASE del Trentino.

BÉLAND, Daniel. 2005. "Ideas and Social Policy: An Institutionalist Perspective." Social Policy and Administration 39(1): 1-18.

BENEDICTO, Jorge and Maria Luz MORÁN. 2007. "Becoming a Citizen.” European Societies 9(4): 601-622.

BRADBURY, Judith A. 1989. "The Policy Implications of Differing Concepts of Risk.” Science, Technology, \& Human Values 14(4): 380-399.

BRAUN, Virginia and Victoria CLARKE. 2006. "Using Thematic Analysis in Psychology." Qualitative Research in Psychology 3(2): 77-101

CALIENDO, Marco and Ricarda SCHMIDL. 2016. "Youth Unemployment and Active Labor Market Policies in Europe." IZA Journal of Labor Policy 5: 1.

CHEVALIER, Tom and Bruno PALIER. 2014. "The Dualisation of Social Policies Towards Young People in France: Between Familism and Activation." Pp. 189-209 in Young People and Social Policy in Europe, edited by Lorenza ANTONUCCI, Myra HAMILTON and Steven ROBERTS. Basingstoke: Palgrave Macmillan.

CHISHOLM, Lynne, Siyka KOVACHEVA and Maurizio MERICO, eds. 2011. European Youth Studies: Integrating Research, Policy and Practice. Innsbruck: M.A.EYS. Consortium. Retrieved October 16, 2017 (http://www.youthstudies.eu/files/maeysreader.pdf).

CICOGNANI, Elvira and Erik AMNÅ. 2016. CATCH-EyoU: Public Authorities Engaging with Youth: Policy Documents and Interviews: Italy: v01. University of Bologna. Retrieved October 16, 2017 (http://amsacta.unibo.it/5486/)

CORDELLA, Giulia and Sara Elisabetta MASI. 2012. Condizione Giovanile e Nuovi Rischi Sociali: Quali politiche? Rome: Carocci.

COUNCIL OF THE EUROPEAN UNION. 2012. "Council Conclusions of 11 May 2012 on Fostering the Creative and Innovative Potential of Young People." Official Journal of the European Union: C 169/1- C 169/4. Retrieved October 16, 2017 (http://www.alliance-network.eu/). 
D’ELIA, Annibale. 2006. Le Politiche Giovanili: Origini, Evoluzione, Stato dell'Arte. Assessorato alla Trasparenza ed alla Cittadinanza Attiva- Regione Puglia, Dipartimento di Scienze Storiche e Sociali - Università degli studi di Bari.

DOTA, Francesca. 2010. "Lo Tsunami della Disoccupazione Giovanile.” Retrieved October 13, 2015 (http://www.linkbari.it/storia/2010/molecole-lo-tsunami-della-disoccupazionegiovanile).

DUNN, William N. 1981. Public Policy Analysis: An Introduction. Englewood Cliffs, NJ: Prentice-Hall.

EUROFOUND. 2014. Social Situation of Young People in Europe. Luxembourg: Publications Office of the European Union.

EUROPEAN COMMISSION. 2009. An EU Strategy for Youth: Investing and Empowering - A Renewed Open Method of Coordination to Address Youth Challenges and Opportunities. Retrieved September 15, 2017 (http://eur-lex.europa.eu).

GOVERNMENT OF ITALY. n.d. Politiche Giovanili - Youth Policies. Retrieved January 26, 2016 (http://leg16.camera.it/465?area=18\&tema=233\&Politiche+giovanili\#paragrafo2796).

GUIDI, Riccardo. 2014. "Youth Policies in Europe: Big Changes After the Big Crisis? An Explorative Analysis.” SocietàMutamentoPolitica: Rivista Italiana di Sociologia 5(10): 241-264.

HEINZ, Walter R. 2009. "Youth Transition in an Age of Uncertainty." Pp. 3-13 in Handbook of Youth and Young Adulthood: New Perspectives and Agendas, edited by Andy FURLONG. New York: Routledge.

HELVE, Helena, Carmen LECCARDI and Siyka KOVACHEVA. 2011. "Youth Research in Europe." Pp. 61-72 in European Youth Studies: Integrating Research, Policy and Practice, edited by Lynne CHISHOLM, Syika KOVACHEVA and Maurizio MERICO. Innsbruck: M.A. EYS Consortium. Retrieved October 16, 2017 (http://www.youthstudies.eu/files/maeysreader.pdf).

HOWARTH, Caroline. 2006. "A Social Representation is Not a Quiet Thing: Exploring the Critical Potential of Social Representations Theory.” British Journal of Social Psychology 45(1): 65-86.

IARD. 2001. Study on the State of Young People and Youth Policy in Europe: Final reports Vol. 1: Executive Summary and Comparative Reports.

JONES, Emma and John GAVENTA. 2002. Concepts of Citizenship: A Review. Brighton: Institute for Development Studies.

MESA, Diego. 2010. "Le Politiche Giovanili in Italia: Attori, Prospettive e Modelli di Intervento." Autonomie Locali e Servizi Sociali 2: 261-274.

MacDONALD, Robert and Jane MARSH. 2001. "Disconnected Youth?” Journal of Youth Studies 4(4): 373-391.

McLAUGHLIN, Milbrey Wallin. 1987. "Learning from Experience: Lessons from Policy Implementation.” Educational Evaluation and Policy Analysis 9(2): 171-178.

OECD. 2014. Income Inequality Update - June 2014. Retrieved April 15, 2017 (www.oecd.org/els/soc/ OECD2014-Income-Inequality-Update.pdf).

POAT - Piano Operativo Assistenza Tecnica. 2014. "Il Quadro di Riferimento per le Politiche Giovanili." Retrieved January 26, 2017 (http://www.poatgioventu.it/).

SIURALA, Lasse. 2006. A European Framework for Youth Policy. Directorate of Youth and Sport, Council of Europe Publishing.

UNITED NATIONS. 1996. "World Programme of Action for Youth to the Year 2000 and Beyond." Retrieved October 16, 2017 (https://europa.eu/capacity4dev/iesf/documents).

VILLANO, Paola and Alberto BERTOCCHI. 2014. "On Active Citizenship: Discourses and Language about Youth and Migrants in Italy." Journal of Civil Society 10(1): 82-99.

WALLACE, Claire and Rene BENDIT. 2009. "Youth Policies in Europe: Towards a Classification of Different Tendencies in Youth Policies in the European Union." Perspectives on European Politics and Society 10(3): 441-458. 
D. Mazzoni, E. Cicognani, Ch. Cifatte, C. Albanesi, B. Zani, L. Floresta: Italian Young People...

WALTHER, Andreas, Gry Moerch HEJL and Torben Benchmann JENSEN. 2002. Youth Transitions, Youth Policy and Participation. Research Project YOYO. Tubingen: IRIS.

WILLIAMSON, Howard. 2011. "A Complex but Increasingly Coherent Journey? The Emergence of 'Youth Policy' in Europe.” Pp. 136-148 in European Youth Studies: Integrating Research, Policy and Practice, edited by Lynne CHISHOLM, Syika KOVACHEVA and Maurizio MERICO. Innsbruck: M.A. EYS Consortium. Retrieved October 16, 2017 (http://www.youthstudies.eu/files/ maeysreader.pdf).

WOLF, Maria, Camilla BLOMQUIST, Rupa HUQ, Erzebeth KOVACS, Howard WILLIAMSON and Peter LAURITZEN. 2004. Youth Policy in Norway: Report by the International Team of Experts. Strasbourg: Council of Europe.

\section{Authors}

Davide Mazzoni is Research Fellow at the University of Milano-Bicocca and was part of the Italian team of the project CATCH-EyoU. His primary scholarly interest concerns the processes of people's empowerment and its possible outcomes at individual and collective level.

Contact: davide.mazzoni@unimib.it

Elvira Cicognani is Full Professor of Social and Community Psychology at the University of Bologna and coordinator of the CATCH-EyoU project. Her research interests concern the psychosocial factors and processes influencing civic and political engagement and participation, particularly among youth; interventions aimed at enhancing youth engagement and active citizenship; psychosocial factors in health behaviours and community health promotion interventions.

Contact: elvira.cicognani@unibo.it

Chiara Cifatte is Community Psychologist, working on regeneration urban processes. She is $\mathrm{PhD}$ in Migration and Intercultural Processes and Professor on contract at Gabriele D'Annunzio University in Chieti for the laboratory of social psychology. She was part of the Italian research team of CATCH E-yoU Project, in 2016.

Contact: chiaracifatte@gmail.com

Cinzia Albanesi is Associate Professor of Community Psychology at the University of Bologna. Her research interests concern participatory practices, including participatory action research, community health promotion, coalitions and university-community partnership.

Contact: cinzia.albanesi@unibo.it

Bruna Zani is Professor of Social and Community Psychology at the University of Bologna, and member of the Executive Council of EFPA (European Federation of Psychologists Associations). She is a member of the Italian team of the project CATCH-EyoU. Her main research interest are risk behaviours in adolescence, civic engagement and political participation in adolescents and young people, service-learning methodology in higher education; evaluation of community interventions on health promotion, theatre and mental health.

Contact: bruna.zani@unibo.it 
Lorenzo Floresta is an expert in European youth policy. With a Master degree in Law and International Master in European Studies, he was the President of Giovani Senza Frontiere (GIOSEF) from 2010 to 2017. Freelancer, working as a project manager and policy advisor of private and public body, NGOs and non-profit organizations. From 2012 to 2015 he was board member of the Italian National Youth Council, where he also held the position of Vice President of the Foreign Commission and the person in charge for the Pool of trainer within "Non Formal Education" working group.

Contact: lorenzo.floresta@gmail.com 